\title{
Correction to: Emergency remote teaching in higher education: mapping the first global online semester
}

\author{
Melissa Bond ${ }^{1 *}$, Svenja Bedenlier ${ }^{2}$, Victoria I. Marín ${ }^{3}$ and Marion Händel ${ }^{2}$
}

The original article can be found online at https://doi. org/10.1186/s41239-02100282-x

\section{${ }^{*}$ Correspondence:}

melissa.bond@ucl.ac.uk

1 EPPI-Centre, Institute

of Education, University

College London, London, UK

Full list of author information

is available at the end of the article

\section{Correction to: Int J Educ Technol High Educ (2021) 18:50 \\ https://doi.org/10.1186/s41239-021-00282-x}

Following publication of the original article (Bond et al., 2021), it was reported that due to a typesetting error Figs. 1-4 in the HTML version of the article were incorrect. The figures were correct in the PDF version of the published article.

The article has been corrected so that the figures in the HTML version of the article match those in the PDF.

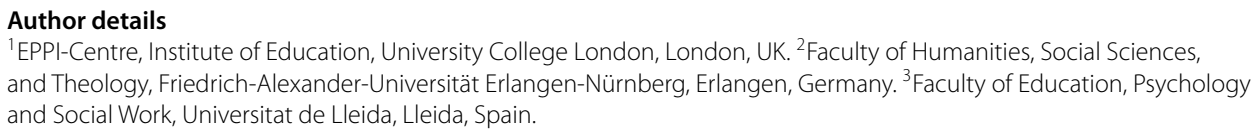
and Theology, Friedrich-Alexander-Universität Erlangen-Nürnberg, Erlangen, Germany. ${ }^{3}$ Faculty of Education, Psychology and Social Work, Universitat de Lleida, Lleida, Spain.

Published online: 22 September 2021

Reference

Bond, M., Bedenlier, S., Marín, V. I., \& Händel, M. (2021). Emergency remote teaching in higher education: Mapping the first global online semester. International Journal of Educational Technology in Higher Education, 18, 50. https://doi. org/10.1186/s41239-021-00282-x

\section{Publisher's Note}

Springer Nature remains neutral with regard to jurisdictional claims in published maps and institutional affiliations. author(s) and the source, provide a link to the Creative Commons licence, and indicate if changes were made. The images or other third party material in this article are included in the article's Creative Commons licence, unless indicated otherwise in a credit line to the material. If material is not included in the article's Creative Commons licence and your intended use is not permitted by statutory regulation or exceeds the permitted use, you will need to obtain permission directly from the copyright holder. To view a copy of this licence, visit http:// creativecommons.org/licenses/by/4.0/. 